\title{
JENIS DAN PENGARUH KEBERADAAN ALGA FILAMEN \\ PADA KEGIATAN BUDIDAYA Eucheuma cottonii DI PERAIRAN TELUK KOTANIA, SERAM BAGIAN BARAT, MALUKU (The Effect of the Existence of Filament Algae on Eucheuma Cottonii Cultivation Activity in Kotania Gulf Waters, West Seram, Maluku
}

\author{
Wahyu Purbiantoro ${ }^{1}$, Wida Lesmanawati ${ }^{2}$, Hairati Arfah ${ }^{1}$ \\ ${ }^{1}$ UPT. Balai Konservasi Biota Laut Ambon, Puslit Oseanografi - LIPI \\ Jln. Y. Syaranamual, Guru-Guru, Poka, Ambon - Maluku 97233. \\ wahyu.purbiantoro@gmail.com \\ 2Program Diploma, Institut Pertanian Bogor
}

Diterima 17 April 2013/ Disetujui 13 Mei 2013

\begin{abstract}
The success of Eucheuma cottonii cultivation in the Gulf Kotania, West Seram, Maluku was influenced by various factors, one of them was the existence of filament algae. This study aims to identify filament algae patching on the thalus $E$. cottonii, the influence of filament algae biomass on specific growth rate (SGR) of E. cottonii in trial raft and the differences of filament algae biomass patching on the thalus E. cottonii cultivated by local people in three different locations. The first study was conducted in trial raft, then the identifications and measurements of filament algae biomass patching on the thalus and the measurements of $E$. cottonii biomass were performed on day 34 and 50. In the second study, the identifications and measurements of filament algae biomass patching on the thalus $E$. cottonii has been done on the three difference locations where E. cottonii has been cultivated by local people. The results showed that Lyngbia sp. was a species of filament algae found in thalus $E$. cottonii in which the algae patch on. The presence of filament algae on the thalus with biomass ratio 1:81, did not affect significantly on SGR of E. cottonii in trial raft. Meanwhile, filament algae biomass obtained from three different locations showed a significant difference, where the filament algae biomass in Wael Village was the highest.
\end{abstract}

Keywords: Filament Alga, Lyngbia sp., Eucheuma cottonii, Gulf Kotania

\section{PENDAHULUAN}

Pemerintah Indonesia melalui Kementerian Kelautan dan Perikanan (KKP) menargetkan produksi rumput laut sebanyak 10 juta ton atau setara 1 juta ton rumput laut kering pada 2014. Target tersebut naik dua kali lipat dibandingkan realisasi 2012 sebesar 5 juta ton, yang menempatkan Indonesia sebagai negara penghasil rumput laut terbesar di dunia (KKP 2013). Target tinggi yang ditetapkan pemerintah tidak hanya untuk memenuhi kebutuhan dunia akan rumput laut yang terus meningkat, namun industrialisasi rumput laut yang dicanangkan pemerintah membutuhkan upaya pemenuhan bahan baku secara sinambung untuk menjamin kapasitas produksi yang diperlukan.

Ekstensifikasi area budidaya rumput laut diperlukan sebagai upaya untuk memenuhi target produksi yang telah ditetapkan. Saat ini diperkirakan area budidaya rumput laut di Indonesia mencapai 1,1 juta ha yang didominasi jenis Eucheuma cottonii (KKP 2013). Jenis E. cottonii merupakan jenis rumput laut karaginofit yang banyak dibudidayakan karena permintaan pasar dunia delapan kali lebih besar dibandingkan jenis $E$. spinosum (Sulistijo 2002). Kondisi tersebut mendorong masyarakat pesisir di Indonesia tidak terkecuali masyarakat di sekitar perairan Teluk Kotania, Seram Bagian Barat, Maluku untuk mempraktekkan budidaya E. cottonii meskipun wilayah ini dikenal sebagai penghasil Eucheuma spp. yang dipanen dari alam (Maail 1980 diacu dalam Rahayu 1984).

Keberhasilan budidaya $E$. cottonii dipengaruhi oleh berbagai faktor, baik faktor fisik, kimia ataupun biologi. Salah satu faktor biologi yang dapat menjadi penghambat produktivitas pada budidaya $E$. cottonii yaitu gangguan biologis berupa keberadaan alga penempel, khususnya alga filamen yang seringkali menyelimuti permukaan talus $E$. cottonii. Kehadiran alga filamen, selain dapat mengundang pemangsa (Atmadja 1991 diacu dalam Atmadja 1999), dalam jumlah besar dapat menggangu pertumbuhan dari $E$. cottonii karena bersifat kompetitor dalam menyerap unsur hara dan menghambat proses fotosintesis sehingga dapat menyebabkan kematian secara perlahan terhadap tanaman inang (Sulistijo 2002; Yulianto 2003). Penelitian ini bertujuan untuk mengetahui jenis alga filamen yang menempel pada talus $E$. cottonii, pengaruh biomassa alga filamen terhadap laju pertumbuhan harian $E$. cottoni di rakit uji coba serta perbedaan biomassa alga filamen pada talus $E$. cottonii yang dibudidayakan masyarakat di tiga lokasi berbeda di Perairan Teluk Kotania, Seram Bagian Barat, Maluku.

\section{METODOLOGI}

Penelitian dilakukan di Perairan Teluk Kotania, Seram Bagian Barat, Maluku (2 $58^{\prime} 00^{\prime \prime}-3^{\circ} 04^{\prime} 00^{\prime \prime}$ LS dan $128^{\circ} 00^{\prime} 00^{\prime \prime}-128^{\circ} 08^{\prime} 00^{\prime \prime}$ BT; Gambar 1) yang berjalan selama dua periode. Periode pertama 
dilakukan pada bulan Mei - Juli 2008 dan periode kedua dilakukan pada bulan Mei - Agustus 2009. Pemilihan waktu penelitian dilandasi alasan keberadaan alga filamen yang umumnya melimpah pada akhir musim peralihan menuju ke musim kemarau dan awal musim kemarau.

Pengambilan dan pengukuran sampel pada periode pertama dilakukan di rakit uji coba budidaya Eucheuma cottonii di sebelah barat Pulau Buntal (Gambar 1). Rakit uji coba berukuran $585 \mathrm{~m}^{2}$ (13 m x $45 \mathrm{~m}$ ) menerapkan sistem long line dengan konstruksi tali tambang sebagai kerangka dengan jerigen dan botol bekas kemasan air minum sebagai pelampung. Penanaman dilakukan dengan menggunakan bibit vegetatif (ujung $E$. cottonii) dengan berat awal sebesar $65 \mathrm{~g}$ yang diikat tali nilon pada tali tambang. Jarak rumpun satu dengan rumpun yang lain pada setiap kolom (rawai) adalah $30 \mathrm{~cm}$ dan jarak kolom satu dengan kolom lain adalah 1,6 m. Ikatan bibit pada tali nilon dibuat sedemikian rupa sehingga bergantung bebas, mudah dilepas dan mudah diikatkan kembali setelah ditimbang, tetapi cukup kuat sehingga tidak lepas bila terkena arus air (Gambar 2).

Identifikasi dan pengukuran biomassa (bobot basah [g]) dari E. cottonii serta alga filamen yang menempel pada talus dilakukan secara acak pada bagian tepi (12 sampel) dan tengah rakit ( 9 sampel) sebanyak dua kali selama masa penanaman yakni pada hari ke 34 (Juni) dan hari ke 50 (Juli) bersamaan dengan waktu pemanenan. Sampel E. cottoni yang diambil pada hari ke 34 dikembalikan lagi pada rakit budidaya namun terlebih dahulu ditandai sehingga menghindari pengambilan ulang ketika dilakukan pengambilan sampel pada hari ke 50. Area pengambilan sampel pada konstruksi rakit uji coba dapat dilihat pada Gambar 2.

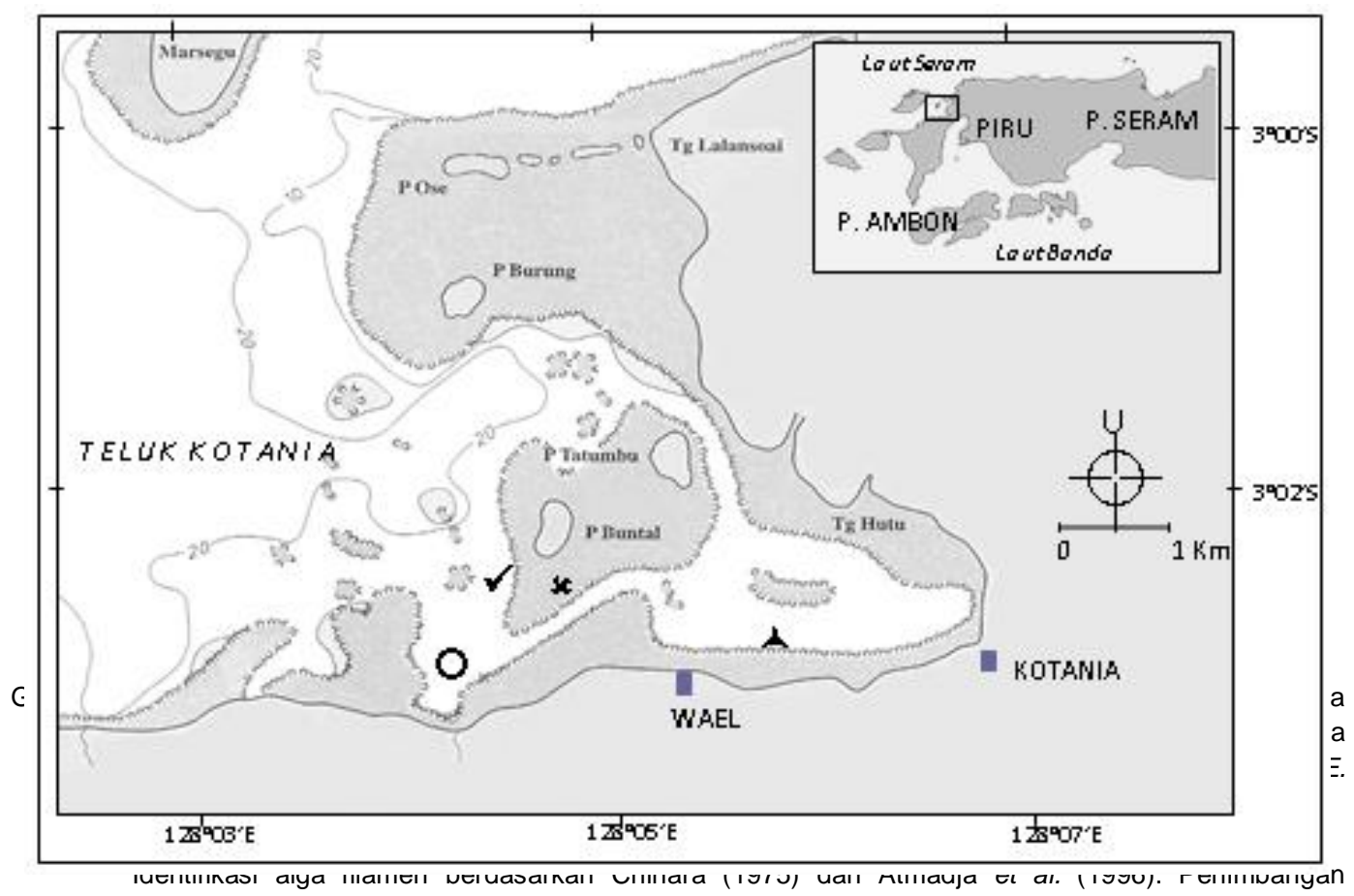

biomassa $E$. cottonii dilakukan dengan menggunakan timbangan digital kapasitas maksimum $10 \mathrm{~kg}$ dan minimum $20 \mathrm{~g}$, sedangkan biomassa alga filamen menggunakan timbangan digital kapasitas maksimum $320 \mathrm{~g}$ dan minimum $10 \mathrm{mg}$. Adapun perhitungan laju pertumbuhan harian (SGR) E. cottonii dihitung berdasarkan Sulistijo (2002):

$$
\text { Laju Pertumbuhan Harian (SGR) }=\left[\left(\frac{W_{n}}{W_{o}}\right)^{1 / n}-1\right] \times 100 \%
$$

$\mathrm{SGR}=$ laju pertumbuhan harian $\left(\%\right.$ hari $\left.^{-1}\right) ; \mathrm{W}_{\mathrm{o}}=$ bobot $E$. cottonii hari ke $0(\mathrm{~g}) ; \mathrm{W}_{\mathrm{n}}=$ bobot $E$. cottonii hari ke $\mathrm{n}$ (g); $\mathrm{n}$ = lama penanaman (hari) 

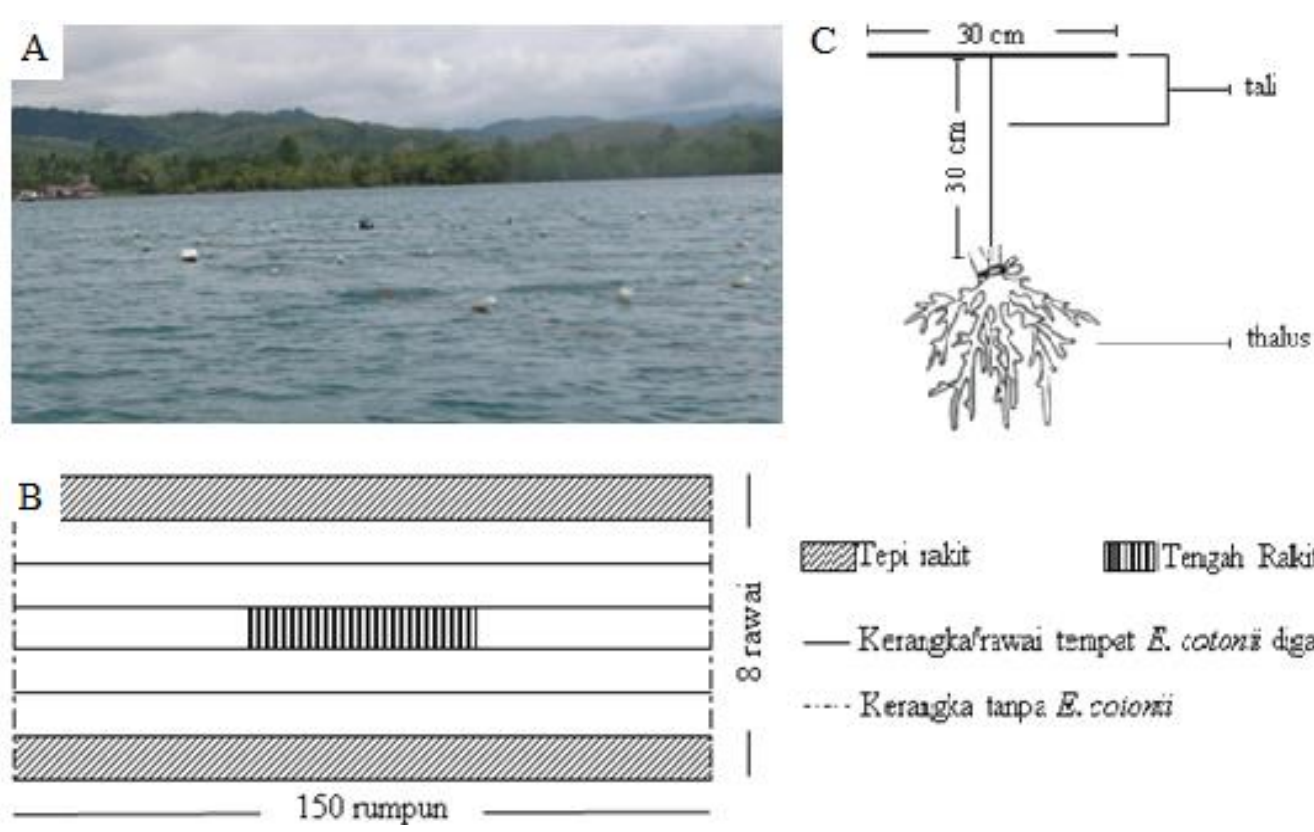

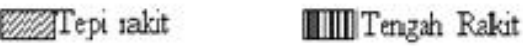

- Keratgkalrawai tenpet $E$. cotonz diganting

-.... Reragiga tanpa E. coioni

Gambar 2 (A) Rakit uji coba budidaya E. cotonii di sebelah barat Pulau Buntal (B) Area pengambilan sampel pada tepi dan tengah rakit budidaya, $(\mathrm{C})$ teknik pengikatan bibit rumput laut pada tali rawai

Kegiatatan penelitian yang dilakukan selama periode kedua berupa identifikasi dan pengukuran biomassa (bobot basah [g]) alga filamen pada E. cottonii yang dibudidayakan masyarakat, tanpa dilakukan pengukuran biomassa $E$. cottonii. Pengambilan sampel alga filamen dilakukan di bulan Mei, Juli dan Agustus pada tiga lokasi budidaya $E$. cottonii yang berbeda, yaitu E. cottonii yang dibudidayakan di sekitar muara sungai, muka Pulau Buntal dan muka Desa Wael (Gambar 1). Pada masing-masing lokasi dipilih tiga rakit budidaya $E$. cottonii kemudian diambil tiga sampel pada masing-masing rakit tersebut sebagai ulangan. Sampel diambil secara acak pada bagian tengah rakit, sebab bagian ini umumnya jarang dibersihkan.

Data yang diperoleh pada periode pertama, dianalisis dengan uji t (independent sample t test) untuk menguji ada tidaknya perbedaan biomassa alga filamen yang menempel pada talus dan SGR E. cottonii yang ditanam di tepi dengan di tengah rakit uji coba. Untuk mengetahui ada tidaknya hubungan antara biomassa alga filamen dengan SGR E. cottonii digunakan uji korelasi bivariate (product moment Pearson). Sementara, untuk menguji ada tidaknya perbedaan biomassa alga filamen pada periode kedua digunakan one way ANOVA (Flower dan Cohen 1990; Irianto 2004).

Data yang digunakan untuk keperluan pengujian statistik telah melewati uji normalitas (KolmogorovSmirnov dan Shapiro-Wilk test) dan uji kesamaan varian (Levene test) untuk memenuhi asumsi yang digunakan dalam pengujian statistik tersebut (Santoso 2008). Transformasi data biomassa alga filamen menggunakan rumus tranformasi logaritma log $(x+1)$ karena adanya hitungan nol pada data yang akan diolah (Flower dan Cohen 1990). Semua perhitungan statistik diolah dengan menggunakan Statistical Product and Service Solutions 16.

Parameter hidrologi yang diukur berupa kecerahan, suhu, salinitas, $\mathrm{pH}$, oksigen terlarut serta kadar nutrien (nitrat dan fosfat). Pengambilan sampel air laut untuk mengetahui kandungan oksigen terlarut dan kadar nutrien menggunakan botol Nansen pada kedalaman $0 \mathrm{~m}$ (permukaan) dan $5 \mathrm{~m}$. Analisis nitrat dan fosfat dilakukan di laboratorium dengan memakai metode Strickland dan Parsons (1968).

\section{HASIL DAN PEMBAHASAN}

\section{Gambaran Umum Lokasi dan Kondisi Hidrologi Perairan}

Kawasan Teluk Kotania terbentuk atas tiga ekosistem utama, yaitu atas terumbu karang (coral reef), padang lamun (seagrass bad) dan mangrove yang saling berdampingan secara harmonis. Kawasan ini terlindung dari hempasan ombak karena di mulut teluk terdapat pulau-pulau kecil, antara lain Pulau Marsegu, Pulau Burung, Pulau Tatumbu, Pulau Osi dan Pulau Buntal.

Hasil pengamatan terhadap substrat di lokasi penelitian menunjukkan bahwa tiap lokasi memiliki komposisi substrat yang berbeda satu sama lainnya. Komposisi substrat di Desa Wael lebih didominasi oleh lumpur dengan sedikit pasir dan pecahan terumbu karang, sementara di Pulau Buntal komposisi substrat berupa pasir berlumpur dan pecahan karang. Namun secara umum substrat pada dasar perairan terdiri atas lumpur, lumpur berpasir serta lumpur dengan pecahan terumbu karang. Perairan yang terlindung dari hempasan ombak dan tipe substrat seperti ini merupakan lokasi budidaya rumput laut yang baik (Sulistijo 2002). 
Tabel 1 Parameter hidrologi pada lokasi rakit uji coba budidaya E. cottonii di barat Pulau Buntal pada bulan Mei (M), Juni (J) dan Juli (JL) 2008.

\begin{tabular}{|c|c|c|c|c|c|c|}
\hline \multirow{3}{*}{ Parameter Hidrologi } & \multicolumn{6}{|c|}{ Kedalaman (m) } \\
\hline & \multicolumn{3}{|c|}{0} & \multicolumn{3}{|c|}{5} \\
\hline & M & $\mathrm{J}$ & $\mathrm{JL}$ & M & $\mathrm{J}$ & $J L$ \\
\hline Suhu $\left({ }^{\circ} \mathrm{C}\right)$ & 29,00 & 28,50 & 28,20 & 28,80 & 28,00 & 27,90 \\
\hline Salinitas $(\% \circ)$ & 33,00 & 33,00 & 33,00 & 33,00 & 33,00 & 33,00 \\
\hline $\mathrm{pH}$ & 8,00 & 8,10 & 8,10 & 8,12 & 8,15 & 8,12 \\
\hline Oksigen Terlarut $\left(\mathrm{mL} \mathrm{L}^{-1}\right)$ & 3,88 & 5,06 & 4,47 & 3,87 & 4,51 & 4,32 \\
\hline Nitrat $\left(\mathrm{mg} \mathrm{L}^{-1}\right)$ & 0,044 & 0,021 & 0,002 & 0,053 & 0,027 & 0,003 \\
\hline \multirow[t]{2}{*}{ Fosfat (mg L $\left.{ }^{-1}\right)$} & 0,033 & 0,106 & 0,110 & 0,089 & 0,109 & 0,103 \\
\hline & \multicolumn{2}{|c|}{ M } & \multicolumn{2}{|c|}{$\mathrm{J}$} & \multicolumn{2}{|c|}{$J L$} \\
\hline Kecerahan (m) & \multicolumn{2}{|c|}{7,50} & \multicolumn{2}{|c|}{7,00} & \multicolumn{2}{|c|}{7} \\
\hline
\end{tabular}

Pengukuran parameter hidrologi di lokasi rakit uji coba budidaya E. cotto-nii selama periode pertama, mencatat suhu air laut berkisar pada $27,90-29,00^{\circ} \mathrm{C}$; salinitas $33,00^{\circ}$; $\mathrm{pH} 8,00-8,15$; oksigen terlarut 3,87-5,06 $\mathrm{mL} \mathrm{L}^{-1}$ nitrat 0,0 02-0,053 $\mathrm{mg} \mathrm{L}^{-1}$;fosfat 0,033-0,109 $\mathrm{mg} \mathrm{L}^{-1}$ dan kecerahan 7,00-7,50 m (Tabel 1).

Sementara hasil pengukuran parameter hidrologi yang dilakukan pada periode kedua mencatat suhu air laut berkisar pada $27,10-28,60^{\circ} \mathrm{C}$; salinitas $28,00-34,00 \%$ o; $\mathrm{pH} 8,00-8,70$; oksigen terlarut $3,21-8,72 \mathrm{~mL} \mathrm{~L}^{-1}$; nitrat $<0,001-0,098 \mathrm{mg} \mathrm{L}^{-1}$; fosfat $<0,001-0,001 \mathrm{mg} \mathrm{L}^{-1}$ dan kecerahan 4,00-8,00 m (Tabel 2).

Merujuk klasifikasi yang disusun Sulistijo (2002) berdasarkan komposisi substrat dan kondisi hidrologi perairan selama penelitian dilakukan, lokasi budidaya E. cottonii di perairan Teluk Kotania masuk klasifikasi layak atau baik untuk kegiatan budidaya rumput laut $E$. cottonii walaupun bukan pada kisaran atau kondisi yang optimum. Hal tersebut dikarenakan rendahnya kandungan nitrat dan fosfat pada kolom air saat pengukuran dilakukan. Berdasarkan SNI KKP No. SNI 01-6492-2010 diacu dalam Wantasen dan Tamrin (2012) kadar nitrat dan fosfat pada kolom air untuk menghasilkan pertumbuhan rumput laut yang optimum masing-masing sebesar 1,5- 2,5 dan 0,050-0,075 $\mathrm{mg} \mathrm{L}^{-1}$.

Terdapat beberapa faktor yang mungkin dapat menjelaskan rendahnya kandungan nutrien (nitrat dan fosfat) di perairan Teluk Kotania khususnya di sekitar lokasi budidaya saat pengukuran dilakukan. Pertama, berkurangnya nutrien dari daratan yang masuk ke laut saat musim kemarau. Kadar nitrat dan fosfat dalam kolom air selama pengukuran dilakukan terus mengalami penurunan, di mana kadar nitrat dan fosfat terendah diperoleh di bulan Agustus saat puncak musim kemarau (Tabel 1 dan 2). Kedua, proses pemanfaatan nutrien oleh rumput laut yang dibudidayakan secara intensif ataupun rumput laut dan lamun yang tumbuh di alam. Penelitian yang dilakukan Nishihara dan Ryuta (2010) menemukan bahwa kandungan nutrien pada area rumpun $E$. serra, 56\% lebih rendah dibandingkan di luar area rumpun rumput laut. Selain itu, perairan Teluk Kotania merupakan kawasan yang dipenuhi oleh padang lamun sekaligus rumput laut yang tumbuh secara alami. Kepadatan (standing corp) rumput laut di Pulau Buntal dan di Desa Wael sangat tinggi mencapai $1224,40 \mathrm{~g} \mathrm{~m}^{2}$ dan 1576,60 $\mathrm{g} \mathrm{m}^{2}$ (Arfah dan Purbiantoro in press). Walaupun demikian, rumput laut yang dibudidayakan di lokasi tersebut diduga tetap mendapatkan pasokan nutrien yang cukup dari luar area lokasi budidaya rumput laut terutama dari dekomposisi bahan organik yang dihasilkan oleh ekosistem mangrove. 
Tabel 2 Parameter hidrologi pada lokasi budidaya E. cottonii di sekitar muara sungai, muka Pulau Buntal dan muka pemukiman Desa Wael, perairan Teluk Kotania, Seram Bagian Barat, Maluku pada bulan Mei (M), Juli (J) dan Agustus (A) 2009

\begin{tabular}{|c|c|c|c|c|c|c|c|c|c|}
\hline \multirow{2}{*}{$\begin{array}{l}\text { Kedalaman } \\
\qquad(\mathrm{m})\end{array}$} & \multicolumn{3}{|c|}{ Muara Sungai } & \multicolumn{3}{|c|}{ Pulau Buntal } & \multicolumn{3}{|c|}{ Desa Wael } \\
\hline & $\mathrm{M}$ & $\mathrm{J}$ & $A$ & $M$ & $\mathrm{~J}$ & $A$ & $M$ & J & $A$ \\
\hline \multicolumn{10}{|c|}{ Suhu $\left({ }^{\circ} \mathrm{C}\right)$} \\
\hline 0 & 28,00 & 27,70 & 27,10 & 28,00 & 28,00 & 28,60 & 28,00 & 28,30 & 27,30 \\
\hline 5 & 27,90 & 27,80 & 27,50 & 27,50 & 28,00 & 28,30 & 27,50 & 28,00 & 27,50 \\
\hline \multicolumn{10}{|c|}{ Salinitas $(\% \circ)$} \\
\hline 0 & 32,00 & 34,00 & 33,00 & 31,00 & 34,00 & 33,00 & 32,00 & 32,00 & 32,00 \\
\hline 5 & 31,00 & 34,00 & 28,00 & 32,00 & 34,00 & 32,00 & 32,00 & 32,00 & 32,00 \\
\hline \multicolumn{10}{|c|}{$\mathrm{pH}$} \\
\hline 0 & 8,15 & 8,16 & 8,08 & 8,12 & 8,15 & 8,00 & 8,07 & 8,14 & 8,00 \\
\hline 5 & 8,15 & 8,14 & 8,07 & 8,12 & 8,15 & 8,70 & 8,12 & 8,13 & 8,05 \\
\hline \multicolumn{10}{|c|}{ Oksigen Terlarut $\left(\mathrm{mL} \mathrm{L}^{-1}\right)$} \\
\hline 0 & 8,52 & 3,49 & 4,79 & 8,72 & 3,74 & 4,79 & 7,66 & 4,27 & 4,57 \\
\hline 5 & 7,83 & 3,21 & 5,19 & 7,48 & 3,24 & 4,91 & 7,83 & 3,86 & 4,74 \\
\hline \multicolumn{10}{|c|}{ Nitrat $\left(\mathrm{mg} \mathrm{L}^{-1}\right)$} \\
\hline 0 & 0,091 & 0,013 & 0,002 & 0,007 & 0,007 & 0,002 & 0,098 & 0,002 & 0,001 \\
\hline 5 & 0,060 & 0,012 & 0,005 & 0,079 & 0,005 & 0,005 & 0,016 & 0,012 & $<0,001$ \\
\hline \multicolumn{10}{|c|}{ Fosfat $\left(\mathrm{mg} \mathrm{L}^{-1}\right)$} \\
\hline 0 & 0,001 & $<0,001$ & $<0,001$ & $<0,001$ & $<0,001$ & $<0,001$ & $<0,001$ & $<0,001$ & $<0,001$ \\
\hline 5 & 0,001 & $<0,001$ & $<0,001$ & $<0,001$ & $<0,001$ & $<0,001$ & $<0,001$ & $<0,001$ & $<0,001$ \\
\hline \multicolumn{10}{|c|}{ Kecerahan (m) } \\
\hline & 6,00 & 4,00 & - & 8,00 & 5,00 & 6,50 & 5,00 & 4,50 & 5,00 \\
\hline
\end{tabular}

\section{Kehadiran Alga Filamen}

Hasil pengamatan secara visual periode pertama pada rakit budidaya memperlihatkan keberadaan alga filamen pada talus $E$. cottonii mulai dijumpai pada akhir minggu pertama, baik di tepi mapun di tengah rakit uji coba. Yulianto (2003) menyebutkan alga filamen umumnya mulai muncul di awal musim kemarau saat perairan tenang dari ombak. Keberadaan alga filamen tersebut cukup menggangu karena melilit dan menyelimuti permukaan talus sehingga sulit dibersihkan. Hasil identifikasi menemukan satu jenis alga filamen yang menempel pada talus E. cottonii, yaitu Lyngbia sp. (Gambar 3). Penelitian Atmadja dan Sulistijo (1978) pada percobaan budidaya $E$. spinosum di Pulau Pari menemukan jenis alga filamen yang sama. Alga filamen jenis Lyngbia sp. termasuk salah satu dari jenis cyanobacteria. Organisme tersebut merupakan prokaryotic oxygenic phototrophs yang dapat ditemukan pada berbagai habitat dipermukaan bumi (Garcia-Pichel dan Pringault 2001; Dutta et al. 2005) dan hidup dalam berbagai karakteristik morfologi berlainan mencakup uniseluler dan filamen (Castenholz 2001 diacu dalam Abed et al. 2008).
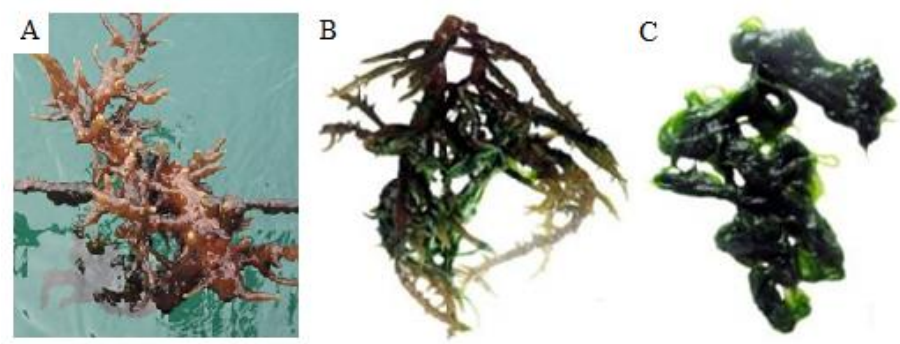

Gambar 3 Talus E. cottonii yang diselimuti alga filamen (Lyngbia sp.): A) kondisi talus terikat pada tali tambang, B) kondisi talus dilepas dari tali pengikat, dan C) Lyngbia sp. yang sudah dipisahkan dari talus 
Berdasarkan tempat pengambilan sampel pada rakit uji coba, E. cottonii yang ditempatkan di tengah rakit uji coba diselimuti alga filamen jauh lebih banyak dibandingkan dengan $E$. cottonii yang ditanam di tepi rakit uji coba. Hal ini selaras dengan hasil $t$ test antara $E$. cottonii yang ditempatkan di tepi dengan tengah rakit uji coba yang menunjukkan perbedaan nyata baik pada hari ke 34 (BF34, $p<0,025)$ maupun pada hari ke 50 (BF 50, $p<0,025$; Tabel 3).

Perbedaan biomassa alga filamen di tepi maupun di tengah rakit uji coba tidak berpengaruh terhadap SGR E. cottonii, baik pada hari ke 34 (SGR34, p>0,025) maupun pada hari ke 50 (SGR50, p>0,025; Tabel 3). Uji korelasi bivariate/product moment Pearson yang dilakukan menegaskan tidak ada korelasi antara banyaknya biomassa alga filamen yang ditemukan dengan SGR E. cottonii baik pada tepi ataupun tengah rakit uji coba, pada hari ke $34(p>0,025)$ maupun hari ke $50(p>0.025)$. Kondisi $E$. cottonii keseluruhan baik pada tepi ataupun tengah rakit uji coba walaupun diselimuti alga filamen memiliki SGR sebesar 3,92-5,49\% hari ${ }^{-1}$ (Tabel 3). Berdasarkan Sulistijo dan Syafri (1991) diacu dalam Sulistijo (2002) SGR Eucheuma sebesar 3-5\% hari-1 tergolong baik dengan kadar karaginan sebesar $35-45 \%$ (masa penanaman enam minggu). Hal ini dapat diartikan bahwa keberadaan alga filamen yang menempel pada talus $E$. cottonii dengan perbandingan biomassa 1:81 belum menimbulkan gangguan berarti terhadap proses fotosintesis dan kompetisi perebutan unsur hara karena persentasi penutupan alga filamen terhadap talus $E$. cottonii masih kecil.

Hasil pengukuran juga menunjukkan bahwa perbedaan waktu pengambilan sampel baik pada tepi atau tengah rakit uji coba tidak berpengaruh nyata terhadap biomassa alga filamen (BF34 dan BF50, $p>0,025$; Tabel 3). Hal sebaliknya terjadi pada SGR E. cottonii (SGR34 dan SGR50) baik pada tepi ataupun tengah rakit uji coba $(p<0,025)$. E. cottoni dengan waktu penanaman yang lebih singkat (SGR34) memiliki SGR yang lebih besar dibandingkan $E$. cottoni dengan waktu penanaman yang lebih lama (SGR50). Kondisi tersebut sesuai dengan yang dipaparkan oleh Papalia (2008) bahwa talus E. cottonii yang masih muda memiliki pertumbuhan vegetatif yang lebih cepat.

Tabel 3 Biomassa E. cottonii awal perlakuan (BRA), hari ke 34 (BR34), hari ke 50 (BR50), biomassa alga filamen hari ke 34 (BF34), hari ke 50 (BF50), laju pertumbuhan biomassa E. cottonii hari ke 34 (SGR34) dan hari ke 50 (SGR50) berdasarkan posisi penanaman bibit E. cottonii pada rakit uji coba budidaya, Mei - Juli 2008

\begin{tabular}{lcc}
\hline & \multicolumn{2}{c}{ Perlakuan } \\
\hline BRA $(\mathrm{g})$ & Tepi & Tengah \\
\hline BR34 $(\mathrm{g})$ & $65,30 \pm 0,17$ & $65,25 \pm 0,09$ \\
\hline BR50 $(\mathrm{g})$ & $416,46 \pm 122,14$ & $413,60 \pm 115,30$ \\
\hline BF34 $(\mathrm{g})$ & $478,72 \pm 169,88$ & $462,12 \pm 126,22$ \\
\hline BF50 $(\mathrm{g})$ & $1,99 \pm 1,03^{\mathrm{a},+}$ & $5,11 \pm 3,15^{\mathrm{b},+}$ \\
\hline SGR34 $\left(\%\right.$ hari $\left.^{-1}\right)$ & $1,21 \pm 1,42^{\mathrm{a},+}$ & $4,03 \pm 4,28^{\mathrm{b},+}$ \\
\hline SGR50 $\left(\%\right.$ hari $\left.^{-1}\right)$ & $5,49 \pm 0,88^{\mathrm{a}, \star}$ & $5,49 \pm 0,82^{\mathrm{a}, \star}$ \\
\hline
\end{tabular}

Ket: Baris dengan huruf $(\mathrm{a}, \mathrm{b})$ atau kolom dengan simbol $\left(+,-\right.$ atau $\left.{ }^{*}, \wedge\right)$ yang sama tidak berbeda nyata pada taraf uji $5 \%$ ( $p>0,025$; independent sample t test, 2-tailed test)

Sementara itu, pengukuran biomassa alga filamen yang menempel pada talus $E$. cotonii dari rakit budidaya di tiga lokasi berbeda, mencatat biomassa alga filamen terbesar diperoleh dari talus $E$. cottonii yang dibudidayakan di muka pemukiman Desa Wael pada bulan Mei $(6,11 \pm 4,01 \mathrm{~g})$. Sebaliknya biomassa alga filamen terkecil diperoleh di dari talus $E$. cottonii yang dibudidayakan di muka Pulau Buntal pada Agustus $(1,50 \pm 0,84 \mathrm{~g})$. Uji one way ANOVA terhadap keberadaan alga filamen dari ketiga lokasi menunjukkan perbedaan nyata pada Mei $(p<0,05)$ dan Agustus $(p<0,05$; Gambar 4). Hal ini disebabkan karena kadar nitrat di bulan Mei dan di muka pemukiman Desa Wael lebih tinggi dibandingkan kadar nitrat di bulan Juli-Agustus dan di dua lokasi lainnya (Tabel 2).

Data pada Tabel 3 (BF34 dan BF50) dan Gambar 4 menunjukkan bahwa pertambahan biomassa alga filamen tidak berkorelasi dengan lama waktu penanaman $E$. cottonii, akan tetapi diduga lebih dipengaruhi oleh faktor fisika dan kimia perairan terutama arus air dan kandungan nutrien. Hutahaean (1992) melaporkan pola arus di Teluk Kotania sangat dipengaruhi oleh kondisi air pasang-surut, dimana kecepatan rata-rata arus permukaan pada saat kondisi pasang dan surut relatif lemah, masing-masing sebesar $0,07 \mathrm{~m} \mathrm{dt}^{-1} \mathrm{dan} 0,11 \mathrm{~m} \mathrm{dt}$ 1. Kecepatan arus permukaan yang lemah menjadikan lokasi ini ideal untuk pertumbuhan alga filamen. 


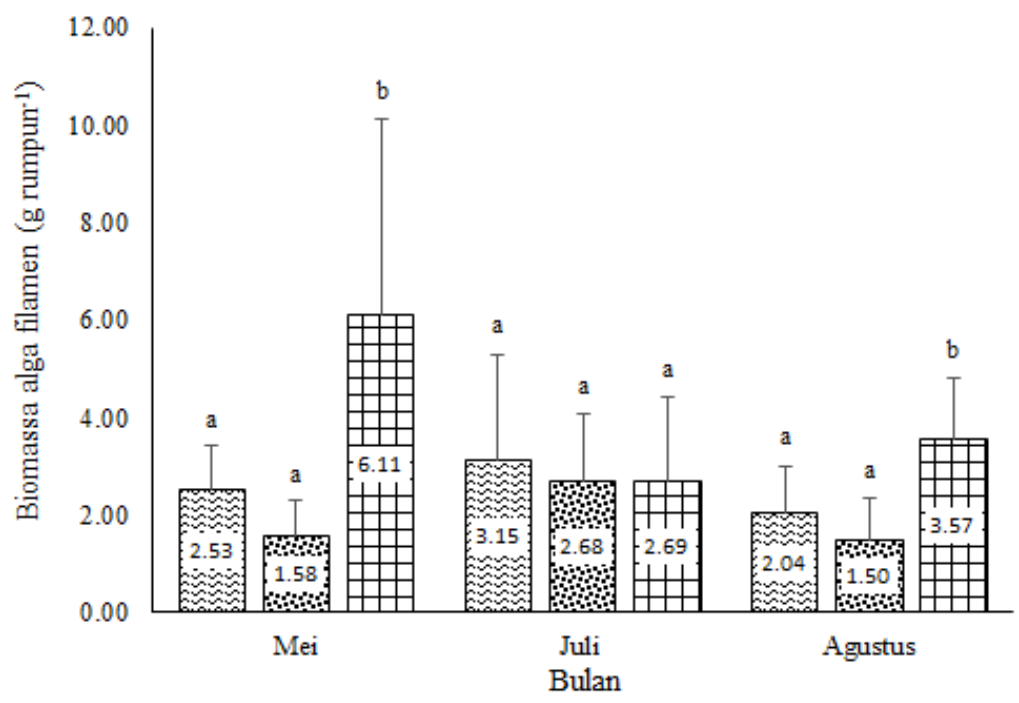

Gambar 4 Biomassa alga filamen berdasarkan lokasi budidaya $E$. cottonii yang diusahakan masyarakat pada Mei, Juli dan Agustus 2009. = sekitar muara sungai, = muka Pulau Buntal, = muka Desa Wael. Kolom dengan huruf sama tidak berbeda nyata pada taraf uji $5 \%(p>0,05$; HSD test)

\section{SIMPULAN}

Lyngbia sp. merupakan jenis alga filamen yang menempel pada talus $E$. cottonii yang dibudidayakan di Teluk Kotania, Seram Bagian Barat, Maluku. Namun keberadaan alga filamen pada talus dengan perbandingan biomassa 1:81, belum memberikan pengaruh nyata terhadap laju perumbuhan biomassa harian (SGR) E. cottonii. Sementara biomassa alga filamen yang diperoleh dari tiga lokasi budidaya E. cottonii yang diusahakan masyarakat menunjukkan perbedaan nyata, dimana biomassa alga filamen di muka pemukiman Desa Wael adalah yang paling tinggi.

\section{DAFTAR PUSTAKA}

Abed RMM, Dobretsov S, Sudesh K. 2008. Applications of cyanobacteria in biotechnology. J Appl Microbiol 106: 1-12.

Atmadja WS, Kadi A, Sulistijo, Rachmaniar. 1996. Pengenalan jenis- jenis rumput laut di Indonesia. Jakarta: Puslitbang Oseanologi-LIPI. 191 hal.

Atmadja WS. 1999. Perkembangan dan makna penelitian rumput laut (algae makro) di Indonesia. Di dalam: Setiawan B et al., editor. Kumpulan naskah orasi ilmiah ahli peneliti utama Pusat Penelitian Oseanografi-LIPI 1995-2004. Jakarta: Pusat Penelitian Oseanografi-LIPI. hal 375-417.

Chihara M. 1975. The seaweeds of Japan. Japan: Gakken Illustrated Nature Encyclopedia. 292 hal.

Flower J, Cohen L. 1990. Practical statistics for field biologi. England: John Wiley and Sons. hal 83-141.

Hutahaean W. 1992. Studi Pendahuluan tentang peran arus dalam proses pengadukan di Teluk Kotania, Seram Barat. Perairan Maluku dan Sekitarnya: 83-88.

Irianto A. 2004. Statistik konsep dasar dan aplikasinya. Jakarta: Kencana. hal 97-154.

[KKP] Kementerian Kelautan dan Perikanan. 2013. Indonesia genjot produksi rumput laut 10 juta ton [internet]. [diacu 2013 April 5]. Tersedia dari: http://www.indonesia.go.id/in/kementerian/kementerian-kelautandan-perikanan/829-kelautan/12153-indonesia-genjot-produksi-rumput-laut-10-juta-ton.

Nishihara GN, Ryuta T. 2010. Spatial variations ini nutrient supply to red algae Eucheuma serra (J. Agardh). Phycological Res 58(1): 29-34.

Papalia S. 2008. Studi budidaya rumput laut Eucheuma cottonii (Rhodophyta) di Perairan Teluk Osi Seram Bagian Barat. Prosiding Seminar Nasional XIX; Makasar 9-10 Juli 2008. Perhimpunan Biologi Indonesia. hal 140-149.

Rahayu DP. 1984. Keanekaragaman jenis dan biomassa rumput laut di beberapa daerah Maluku Tengah. Oseanol Indones 18: 21-34.

Santoso S. 2008. Panduan lengkap menguasai SPSS 16. Jakarta: Elex Media Komputindo. hal 164-272. 
Sulistijo. 2002. Penelitian budidaya rumput laut (algae makro/seaweed) di Indonesia. Di dalam: Setiawan B et al., editor. Kumpulan naskah orasi ilmiah ahli peneliti utama Pusat Penelitian Oseanografi-LIPI 19952004. Jakarta: Pusat Penelitian Oseanografi-LIPI. hal. 531-580.

Wantasen AS, Tamrin. 2012. Analisis kelayakan lokasi budidaya rumput laut di perairan Teluk Dodinga Kabupaten Halmahera Barat. J Perikanan Kelautan Tropis 8 (1): 23-27.

Yulianto K. 2003. Pengamatan penyakit ice-ice dan alga kompetitor fenomena penyebab kegagalan panen budidaya rumput laut (Kappaphycus alvarezii (C) Agardh) di Pulau Pari, Kepulauan Seribu tahun 2000 dan 2001. Prosiding Seminar Riptek Kelautan Nasional; Jakarta 30-31 Juli 2008. hal 100-103. 